Early development of the porcine embryo the importance of cell signalling in development of pluripotent cell lines Hall, Vanessa Jane

Published in:

Reproduction, Fertility and Development

DOI:

10.1071/RD12264

Publication date:

2013

Document version

Early version, also known as pre-print

Citation for published version (APA):

Hall, V. J. (2013). Early development of the porcine embryo: the importance of cell signalling in development of pluripotent cell lines. Reproduction, Fertility and Development, 25(1), 94-102. https://doi.org/10.1071/RD12264 


\title{
Early development of the porcine embryo: the importance of cell signalling in development of pluripotent cell lines
}

\author{
Vanessa Jane Hall \\ University of Copenhagen, Faculty of Health and Medical Sciences, Department of Veterinary \\ Clinical and Animal Sciences, Gronnegaardsvej 7, DK-1870 Frederiksberg C, Denmark. \\ Email:vh@sund.ku.dk
}

\begin{abstract}
Understanding the cell signalling events that govern cell renewal in porcine pluripotent cells may help improve culture conditions and allow for establishment of bona fide porcine embryonic stem cells (pESC) and stable porcine induced pluripotent stem cells (piPSC). This review investigates cell signalling in the porcine preimplantation embryo containing either the inner cell mass or epiblast, with particular emphasis on fibroblast growth factor, SMAD, WNT and Janus tyrosine kinases/signal transducers and activators of transcription signalling. It is clear that key differences exist in the cell signalling events that govern pluripotency in this species compared with similar embryonic stages in mouse and human. The fact that bona fide $\mathrm{pESC}$ have still not been produced and that piPSC cannot survive in culture following the silencing or downregulation of the reprogramming transgenes suggest that culture conditions are not optimal. Unravelling the factor/s that regulate pluripotency in porcine embryos will pave the way for future establishment of stable pluripotent stem cell lines.
\end{abstract}

Additional keywords: cell signalling, embryo, FGF pathway, JAK/STAT pathway, pluripotent stem cells, porcine, preimplantation, SMAD pathway, WNT pathway.

\section{Introduction}

The pig is currently an under-represented model for biomedical studies, but is steadily gaining acceptance as a potential alternative model for studying disease and testing of pharmaceutical products, as well as in regenerative medicine. This is primarily due to the development of new pig models of disease (Rogers et al. 2008; Kragh et al. 2009; Renner et al. 2010; Klymiuk et al. 2012; Luo et al. 2012; Staunstrup et al. 2012), good characterisation of physiological conditions (in particular within miniature pig breeds; Jacobs 2006; Bode et al. 2010; McAnulty et al. 2011) and increased research into embryo technologies and the cell culture of porcine cells (Oestrup et al. 2009; Esteban et al. 2010; Gil et al. 2010; Zhao et al. 2010).

In the case of regenerative medicine, the pig has become of particular interest given the recent breakthroughs in developing in vitro cell models, including porcine (p) induced pluripotent stem cells (iPSCs; Roberts et al. 2009; Esteban et al. 2010), skin-derived progenitor cells (Zhao et al. 2009; Lermen et al. 2010), neural stem/progenitor cells (Uebing-Czipura et al. 2008; Liard et al. 2009; Puy et al. 2010; Rasmussen et al. 2011; Yin et al. 2011; Zhao et al. 2012), peripheral blood-derived multipotent adult progenitor cells (Price et al. 2006; Spitzer et al. 2011), primordial germ cells (Petkov et al. 2011) and mesenchymal stem cells (Rho et al. 2009; Monaco et al. 2011; Miernik and Karasinski 2012). These cells have the capacity to be cultured in vitro and be differentiated into multiple, specific cell types that can be used for studying disease and could be considered for future cell therapy. Furthermore, with the recent development of severe combined immunodeficient pigs lacking interleukin (IL)-2 receptor $\gamma$ (IL2rg), this animal model already presents an excellent step towards developing a model for xenotransplantation studies and for studying diseases, such as human cancers (Suzuki et al. 2012).

Despite these breakthroughs, certain porcine cells have been difficult to culture compared with similar cells obtained from mouse and human. For example, culture of porcine (p) embryonic stem cells (ESCs) has been a particularly difficult task (Brevini et al. 2007a; Hall 2008; Muñoz et al. 2009). The ESCs are derived from either the inner cell mass (ICM) or epiblast (EPI) of the developing preimplantation blastocyst and, to date, no bona fide cell lines from the pig have been reported that recapitulate the features of mouse (m) ESCs (i.e. can be cultured indefinitely in vitro, form cells representative of all three germ layers in vitro and in vivo and can contribute to the germline). Induced pluripotent stem cell lines are reprogrammed somatic cells that recapitulate pluripotent ESC and were first produced in the pig in 2009 (Esteban et al. 2009). Since then, only one research group has reported that these cells can generate chimeras (West et al. 2010) and contribute to the germline (West et al. 2011); however, chimera production was found to be low and germline transmission even lower. Despite the recent advances in the generation of piPSC, these cells are unable to silence the inserted transgenes and, if forced, the repression of these transgenes results in the loss of the ability of 
the piPSC to self-renew in culture (Esteban et al. 2009; Ezashi et al. 2009; Roberts et al. 2009; West et al. 2010; Montserrat et al. 2011; Hall et al. 2012). Reasons for these difficulties have been addressed by many and may be accounted for by differences in embryo development between species (Hall 2008). It is anticipated that piPSC may help simplify the production of transgenic pigs, with the aid of and in combination with more modern transgenic approaches and genetic engineering (Fahrenkrug et al. 2010; Garrels et al. 2012), such as the use of transposons and recombinases (Clark et al. 2007). In addition, despite the recent improvements in the culture of porcine embryos and media composition (Dang-Nguyen et al. 2011; Nguyen et al. 2011; Yoshioka 2011; Liu et al. 2012; Tareq et al. 2012), retaining the pluripotency of either porcine ICM or EPI cells in vitro has been very difficult.

Pluripotent stem cell proliferation and cell renewal is driven by complex cell signalling cascades. These cascades differ markedly between mouse and human pluripotent cells, as does the composition of the media needed to maintain cell pluripotency in vitro. Furthermore, ESCs are in a dynamic equilibrium, which can be observed by the heterogeneous expression of genes such as Nanog and Stella (Chambers et al. 2007; Hayashi et al. 2008). These cascades also differ depending on the embryonic stage the stem cells are recovered from. Recently, proteomic profiling of mESC, epiblast stem cells (epiSC), trophoblast stem cells and extraembryonic endoderm stem cells revealed that unique cell signalling exists on the cell plasma membrane between these different stem cell types (Rugg-Gunn et al. 2012). The culture medium is paramount for maintaining a particular stem cell state and may even radically alter cell fate under the right conditions. This has been shown recently following the reprogramming of mouse fibroblasts into a pluripotent stem cell state for a short transitional period and their subsequent conversion into neural cells simply by growing the reprogrammed cells in a neural-based medium (Kim et al. 2011). Given that bona fide pESC have not been established from any embryonic stage, this infers that culture conditions may not be optimal. This article provides an overview of the cell signalling events known in the developing porcine blastocyst, with special emphasis on the porcine ICM, EPI and trophectoderm (TE). It is anticipated that further studies that can identify cell signalling regulating porcine pluripotency may help improve the culture conditions needed to sustain the growth and retain the pluripotent state of derived pluripotent stem cells in vitro.

\section{Regulation of pluripotency in mouse and human pluripotent stem cells}

More is known about cell signalling governing pluripotency within mESC and human (h) ESC. It has been determined that two modules exist to regulate pluripotency and cell renewal: the Octamer-binding transcription factor 4 (Oct4)-centric and Myc-centric modules. These two modules are multiprotein complexes that are activated downstream of important cell signalling pathways and include several different transcription factors in each. In particular, Oct4, sex-determining region Y-box2 (Sox2), Nanog, mothers against DPP homologue
1 (Smad1), signal transducer and activator of transcription 3 (Stat3) and Tcf3 (Chen et al. 2008; Cole et al. 2008) are known to form the Oct4-centric module, whereas c-Myc, n-Myc, E2f1, Zfx, Rex1 and Ronin are found in the Myc centric module (Chen et al. 2008; Kim et al. 2008; Dejosez et al. 2010). Despite the fact that both species have Oct4, Nanog and Sox 2 as major transcriptional factors that regulate self-renewal (Niwa et al. 2000; Chambers et al. 2007; Masui et al. 2007), recent studies have shown that Oct4 and Nanog bind to different elements in these species. In hESC, OCT4 and NANOG bind to endogenous retroviral sequence 1-repeat transposable elements (ERV1), whereas in $\mathrm{mESC}$ these factors bind to murine-specific endogenous retrovirus K-repeat elements (ERVK; Bourque et al. 2008; Kunarso et al. 2010). A recent report confirms that OCT4, NANOG and SOX2 in hESC control specific cell fate, with OCT4 being shown to modulate four different developmental cell fates and NANOG and SOX2 repressing ectoderm and mesendoderm differentiation, respectively (Wang et al. 2012). Investigations of the post-translational activity of these transcription factors in the mouse has shown that regulation of pluripotency is accomplished by Oct4 binding DNA in multiple heterodimer and homodimer configurations by rapid alteration of activation in response to varying extracellular signals (Saxe et al. 2009). Nanog has been shown to dimerise through its C-terminal domain rather than its homeodomain (Wang et al. 2008).

There are considerable differences in cell signalling between $\mathrm{mESC}$ and hESC. For example, mESC pluripotency is primarily regulated by Janus tyrosine kinases (JAK)/signal transducers and activators of transcription (STAT) signalling, but WNT and bone morphogenetic protein (BMP) signalling is also important in maintaining stemness ( $\mathrm{Ng}$ and Surani 2011). The transcriptional regulation of pluripotency of hESC differs and, moreover, depends on fibroblast growth factor (FGF) and transforming growth factor (TGF)- $\beta$ /ACTIVIN/NODAL signalling (Ng and Surani 2011). It is well known that supplementation of the medium can sustain pluripotent stem cells in vitro; for example, basic (b) FGF/FGF-2 in the case of hESC and leukaemia inhibitory factor (LIF) in the case of mouse ESC, which activate the mitogen-activated protein kinase (MAPK) pathway in hESC (Eiselleova et al. 2009) and the JAK/STAT, phosphatidylinositol 3-kinase (PI3K)/protein kinase B (AKT) and Src homology 2 domain-containing tyrosine phosphatase 2 (SHP2)/MAPK pathways in mESC (Hirai et al. 2011). In addition, bFGF has been shown to activate extracellular signal-regulated kinase (ERK) and the downstream factor cFos (Kang et al. 2005), indicating a strong likelihood of activating mitogen-activated protein kinase kinase (MEK)/ERK signalling, as well as being able to modulate WNT signalling (Ding et al. 2010). These pathways are crucial for maintaining the stemness of the cells in vitro. Without such supplementation, these cells cannot be maintained in vitro.

Another pluripotent stem cell population can be derived from later-stage mouse blastocysts containing the EPI called EpiSCs (Brons et al. 2007), which have similar features to hESC in terms of their cell signalling (Greber et al. 2010). However, despite their ability to form multiple lineages in vitro and teratomas in vivo, the ability of EpiSCs to form chimeras is low and there 
are no reports of germline transmission ( $\mathrm{Ng}$ and Surani 2011). This research sparked the proposal that different pluripotent stem cell states can exist in culture, which may be attributed, in part, to the stage of embryo development they are derived from (Han et al. 2010). Recently, it was confirmed that hESC are derived from a post-ICM intermediate (O'Leary et al. 2012). However, intermittent states or reversion from one pluripotent state to another can also be obtained simply by manipulating the in vitro culture systems or by overexpression of factors (Zhou et al. 2010; Bernemann et al. 2011; Berge et al. 2011; Gu et al. 2012). This has been eloquently shown recently with the discovery that $\mathrm{mESC}$ in culture can spontaneously revert to a totipotent cell state reminiscent of a 2-cell blastomere (termed the '2c state'), lacking Oct4, Nanog and Sox2 expression (Macfarlan et al. 2012). This suggests that culture conditions play a significant role in manipulating the growth and stem cell state of embryo-derived stem cells.

\section{Porcine embryonic cell signalling differs to that observed in mouse and human embryos}

Differences in early porcine embryo development and implantation exist compared with mouse and human embryonic development, and these differences have already been well addressed in recent reports (Hall 2008; Bazer et al. 2009; Oestrup et al. 2009). Given that morphological differences exist, it seems especially rational to consider that cell signalling differences also exist. In fact, reports do show that differences occur at both the transcriptional (Kuijk et al. 2008; Hall et al. 2009, 2010; Oestrup et al. 2009) and epigenetic levels in preimplantation porcine embryos compared with other species (Gao et al. 2010, 2011b). Given that the composition of most currently used media for the culture of pESCs and iPSCs is based on media used for the culture of either mouse or human ESC/ iPSC, it also seems logical to assume that media composition may not be optimal for the porcine. Only a few studies have evaluated cell signalling events related to pluripotency in the preimplantation porcine blastocyst (Kuijk et al. 2008; Hall et al. 2009, 2010; du Puy et al. 2011; Wolf et al. 2011c). Therefore, it is evident that determining whether the FGF and/or LIF pathway, or other important regulatory pathways, are active in porcine pluripotent cells is critical to refine media composition effectively and/or to block the predisposition of these cells to form neural cells (Puy et al. 2010).

Studies that outline the key cell signalling events in the pluripotent populations of the porcine embryo will lead to improvements in cell culture media and, ultimately, improvements in the culture of pluripotent cells derived from the embryo. To date, only a few studies have addressed this. The LIF-activated JAK/STAT pathway has been shown not to be important in the pluripotent ICM and EPI in the pig due to the absence of a LIF receptor (Hall et al. 2009). However, the downstream activator STAT3 is expressed (Hall et al. 2009), which can also be activated by other pathways, such as the WNT pathway in mESC (Hao et al. 2006). Furthermore, FGFR1 has been shown to be exclusively expressed in the EPI, whereas bFGF is produced and likely secreted from the TE, indicating that FGF signalling may occur in the pluripotent EPI (Hall et al.
2009). However, researchers who have attempted to culture pESC in the presence of either FGF, LIF or a combination of both have not had any success (Moore and Piedrahita 1997; Wianny et al. 1997; Brevini et al. 2007b), revealing that supplementation of these growth factors alone does not support pluripotency.

\section{Major reprogramming factors (OCT4, NANOG and SOX2) are expressed differently in early porcine compared with mouse and primate embryos}

The major transcription factors associated with pluripotency in the mouse and human, namely OCT4, NANOG and SOX2, have been well studied in the porcine ICM and EPI, revealing that OCT4 is expressed in both the ICM and TE of the prehatched blastocyst (Vejlsted et al. 2006; Hall et al. 2009). Interestingly, OCT4 expression in the TE has also been demonstrated in human preimplantation embryos, where POU5F1_1A, an isoform of OCT4 (expressed in hESC), is localised in the nucleus of both the TE and ICM and is also expressed in hESC (Cauffman et al. 2006). The expression of OCT4 has also been observed in both the ICM and TE of primate blastocysts (Harvey et al. 2009), showing the pig has greater similarity in expression to primate rather than mouse embryos.

Studies in porcine Embryonic day 5-6 embryos have also shown that the blastocyst containing the ICM lacks NANOG and SOX2 (Hall et al. 2009); however, slightly later embryos containing the early epiblast (Embryonic day 8.5) express both NANOG and SOX2 (du Puy et al. 2011). This differs considerably from both mouse and primate embryos. In the primate blastocyst, it has been shown that NANOG expression precedes OCT4 expression in the ICM (Harvey et al. 2009). It is only in the porcine EPI (in Embryonic day 10 embryos) that exclusive expression of OCT4, NANOG and SOX2 is observed (Hall et al. 2009; du Puy et al. 2011).

Together, these data suggest that the pig embryo has a unique expression profile in the blastocyst containing the ICM that differs to that in both primate and mouse embryos, but that the expression of these transcription factors is similar in the later EPI. Therefore, whether OCT4, NANOG and SOX2 are useful in assessing pluripotent ICM cultured cells is questionable. What remains unknown is whether the cells cultured in vitro can be maintained in the ICM or post-ICM state. Research to date suggests that cultured porcine ICM cells derived from early blastocysts do express OCT4, NANOG and SOX2 in early passages, which may suggest that the cells could enter a postICM state in vitro (du Puy et al. 2011; Wolf et al. 2011a).

\section{Expression of cell surface markers in the porcine EPI and TE compared with mouse and human embryos and ESCs}

Cell surface markers have been used to characterise both mESC and hESC, and include stage-specific embryonic antigen (SSEA)-1 (in the case of mESC) and SSEA-3, SSEA-4, TRA-160 and TRA-1-81 (in the case of hESC). The expression of these cell surface markers has been shown to differ between the two species both in pluripotent cells (Table 1) and embryos (Table 2). We have observed that the porcine early blastocyst (Embryonic day 5-6) expresses SSEA-1 in both the ICM and TE 
Table 1. Expression of cell surface markers previously described in porcine, murine and human embryonic stem cells (ESC), induced pluripotent stem cells (iPSC) and epiblast stem cells (epiSC)

ESC, embryonic stem cell; iPSC, induced pluripotent stem cell; epiSC, epiblast stem cell; +, expression; -, lack of expression; N/D, undetermined; SSEA, stage-specific embryonic antigen. Asterisks indicate weak expression

\begin{tabular}{|c|c|c|c|c|c|c|c|c|}
\hline \multirow[t]{2}{*}{ Marker } & \multicolumn{3}{|c|}{ ESC } & \multicolumn{3}{|c|}{ iPSC } & \multicolumn{2}{|c|}{ epiSC } \\
\hline & Porcine & Murine & Human & Porcine & Murine & Human & Porcine & Murine \\
\hline SSEA-1 & $+^{\mathrm{D}}$ & + & - & $-{ }^{\mathrm{B} /}+{ }^{\mathrm{C}}$ & $+^{\mathrm{A}}$ & ${ }^{\mathrm{A}}$ & $+^{\mathrm{F}}$ & $+^{\mathrm{E}}$ \\
\hline SSEA-3 & $\mathrm{N} / \mathrm{D}$ & - & + & $+{ }^{\mathrm{B} /}-{ }^{\mathrm{C}}$ & $-{ }^{\mathrm{A}}$ & $+{ }^{\mathrm{A}}$ & $\mathrm{N} / \mathrm{D}$ & N/D \\
\hline SSEA-4 & $+{ }^{* \mathrm{D}}$ & - & + & $+{ }^{\mathrm{B} /}+{ }^{* \mathrm{C}}$ & $-{ }^{\mathrm{A}}$ & $+{ }^{\mathrm{A}}$ & $+^{\mathrm{F}}$ & N/D \\
\hline TRA-1-61 & $\mathrm{N} / \mathrm{D}$ & - & + & $+{ }^{\mathrm{B} /}-{ }^{\mathrm{C}}$ & $-{ }^{\mathrm{A}}$ & $+{ }^{\mathrm{A}}$ & $\mathrm{N} / \mathrm{D}$ & N/D \\
\hline TRA-1-81 & N/D & - & + & $+{ }^{\mathrm{B} /}-{ }^{\mathrm{C}}$ & $-{ }^{\mathrm{A}}$ & $+{ }^{\mathrm{A}}$ & N/D & N/D \\
\hline
\end{tabular}

Data are from: ${ }^{\mathrm{A}}$ Maherali and Hochedlinger (2008); ${ }^{\mathrm{B}} \mathrm{Wu}$ et al. (2009); ${ }^{\mathrm{C}}$ Ezashi et al. (2009); ${ }^{\mathrm{D}} \mathrm{ESC}$ derived from upregulation of KLF4 and OCT4 (Telugu et al. 2011); ${ }^{\mathrm{E}}$ Brons et al. (2007); ${ }^{\mathrm{F}}$ Alberio et al. (2010).

Table 2. Expression of cell surface markers in porcine, murine and human blastocysts + , expression; -, lack of expression; N/D, undetermined; SSEA, stage-specific embryonic antigen

\begin{tabular}{|c|c|c|c|c|c|c|c|c|c|c|c|c|}
\hline \multirow[t]{3}{*}{ Marker } & \multicolumn{3}{|c|}{ Inner cell mass } & \multicolumn{3}{|c|}{ Epiblast } & \multicolumn{6}{|c|}{ Trophectoderm } \\
\hline & \multirow[b]{2}{*}{ Porcine } & \multirow[b]{2}{*}{ Murine } & \multirow[b]{2}{*}{ Human } & \multirow[b]{2}{*}{ Porcine } & \multirow[b]{2}{*}{ Murine } & \multirow[b]{2}{*}{ Human } & \multicolumn{3}{|c|}{ Early blastocyst } & \multicolumn{3}{|c|}{ Hatching/hatched blastocyst } \\
\hline & & & & & & & Porcine & Murine & Human & Porcine & Murine & Human \\
\hline SSEA1 & $+{ }^{\mathrm{A}}$ & $+{ }^{\mathrm{B}}$ & $-{ }^{\mathrm{B}}$ & - & $+{ }^{\mathrm{B}}$ & $-{ }^{\mathrm{B}}$ & $-{ }^{\mathrm{A}}$ & $+{ }^{\mathrm{B}}$ & $+{ }^{\mathrm{B}}$ & + & $+{ }^{\mathrm{B}}$ & $+{ }^{\mathrm{B}}$ \\
\hline SSEA3 & $\mathrm{N} / \mathrm{D}$ & $-{ }^{\mathrm{B}}$ & $+{ }^{\mathrm{B}}$ & - & $-{ }^{\mathrm{B}}$ & $+{ }^{\mathrm{B}}$ & $\mathrm{N} / \mathrm{D}$ & $-{ }^{\mathrm{B}}$ & $-{ }^{\mathrm{B}}$ & + & $-{ }^{\mathrm{B}}$ & $-{ }^{\mathrm{B}}$ \\
\hline SSEA4 & $\mathrm{N} / \mathrm{D}$ & $-{ }^{\mathrm{B}}$ & $+{ }^{\mathrm{B}}$ & - & $-{ }^{\mathrm{B}}$ & $+{ }^{\mathrm{B}}$ & $\mathrm{N} / \mathrm{D}$ & $-{ }^{\mathrm{B}}$ & $-{ }^{\mathrm{B}}$ & + & $-{ }^{\mathrm{B}}$ & $-{ }^{\mathrm{B}}$ \\
\hline TRA-1-61 & $\mathrm{N} / \mathrm{D}$ & $-{ }^{\mathrm{B}}$ & $+{ }^{\mathrm{B}}$ & - & $-{ }^{\mathrm{B}}$ & $+{ }^{\mathrm{B}}$ & $\mathrm{N} / \mathrm{D}$ & $-{ }^{\mathrm{B}}$ & $-{ }^{\mathrm{B}}$ & + & $-{ }^{\mathrm{B}}$ & ${ }^{\mathrm{B}}$ \\
\hline TRA-1-81 & $\mathrm{N} / \mathrm{D}$ & $-{ }^{\mathrm{B}}$ & $+{ }^{\mathrm{B}}$ & - & $-{ }^{\mathrm{B}}$ & $+{ }^{\mathrm{B}}$ & N/D & $-{ }^{\mathrm{B}}$ & $-{ }^{\mathrm{B}}$ & + & $-{ }^{\mathrm{B}}$ & $-{ }^{\mathrm{B}}$ \\
\hline
\end{tabular}

Data are from: ${ }^{\mathrm{A}}$ Hall et al. (2010); ${ }^{\mathrm{B}}$ Henderson et al. (2002).

(Hall et al. 2010); however, this expression is lost in the developing EPI (Hall et al. 2010). Instead, SSEA-1 is detected only in the TE in the later embryo (Hall et al. 2010). This temporal change in expression as the porcine embryo develops recapitulates the two different stem cell states cultured in vitro of mESC (ICM state, which express SSEA-1) and hESC (post-ICM state, which lacks SSEA-1). We have also studied the expression of SSEA-3, SSEA-4, TRA-1-60 and TRA-1-81 in porcine embryos collected at Embryonic day 8-10 of development. Expression of these cell surface markers has only been studied in expanded and hatching mouse and human blastocysts containing the presumed ICM and/or EPI by one research group (Henderson et al. 2002; Table 2). In our study, the EPI appears different to that of both human and mouse embryos, expressing none of the cell surface markers within the pluripotent EPI; however, these markers are prominent in the surrounding TE (V. J. Hall and P. Hyttel, unpubl. obs.; Table 2). Further investigations are needed into the expression of SSEA-3, SSEA-4, TRA-1-60 and TRA-1-81 in the earlier porcine embryo. However, on the basis of these unpublished results, we see clear differences in this species, which suggests that the hatched pig embryo containing the EPI has an independent expression profile compared with hatching mouse and human embryos. Interestingly, expression of either SSEA-1 (Ezashi et al. 2009), SSEA-3, SSEA-4, TRA-1-60 and TRA-1-81 (Wu et al. 2009) or SSEA-4 (Esteban et al. 2009) has been observed in piPSC, illustrating that clear differences exist between the different cell lines produced. This may indicate dynamic differences in the cultured porcine stem cell state, which could be related to the reprogramming factors or culture conditions used.

\section{Potential cell signalling pathways in the porcine ICM and corresponding TE}

The porcine pluripotent ICM appears to express very few of the genes studied (Fig. 1). Despite cell pluripotency, the ICM does not appear to express SMAD genes, the WNT receptor $S F R P 1$ or GSK3b, but does express $c-M y c$ (V. J. Hall and P. Hyttel, unpubl. data). A previous study reported that GATA6 was expressed in the porcine ICM only (Kuijk et al. 2008; this is in contrast with observations in the mouse embryo, in which GATA6 expression was also detectable in the TE (Koutsourakis et al. 1999). With the absence of NANOG and SOX2 at this stage of development, the key regulators of pluripotency are largely unknown, but may possibly include c-Myc. Further investigation of JAK/STAT signalling is required in the porcine ICM to better understand the events that govern cell renewal. Very little is also known about signalling in the TE at this stage. However, CDX2 expression has been determined in the TE of in vitro-produced blastocysts (Kuijk et al. 2008; Fig. 1). Interestingly, ultrastructural imaging of the early porcine blastocyst containing the ICM indicates little transcription may be occurring based on the presence of 


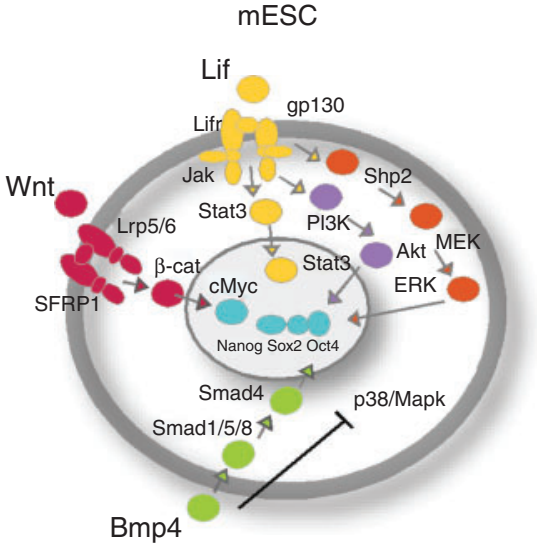

Porcine ICM

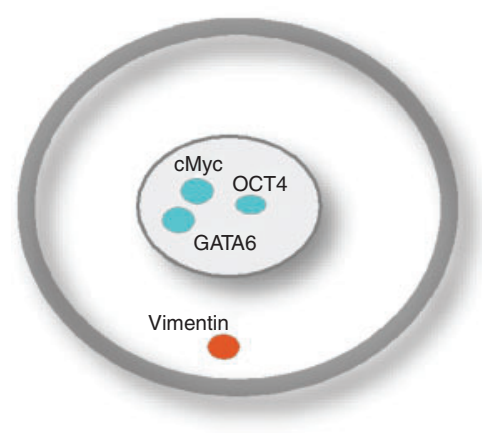

Porcine TE (D6)

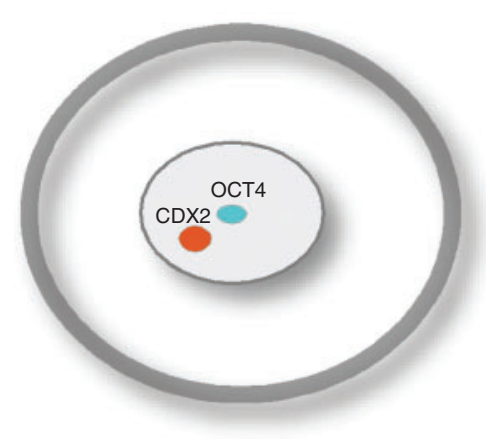

hESC

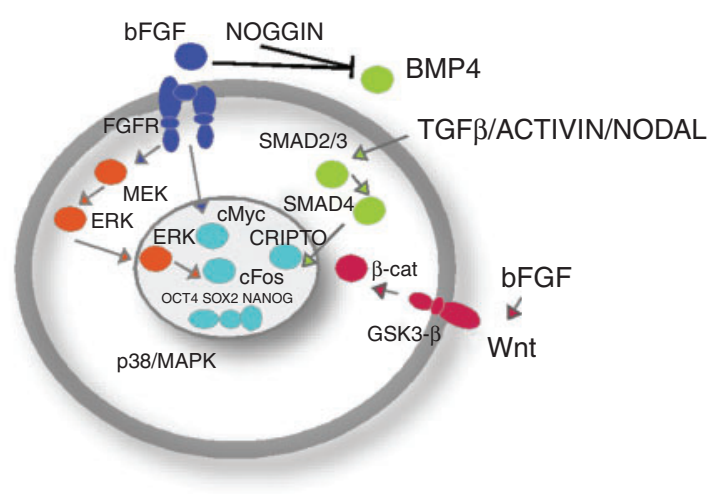

Porcine Epiblast

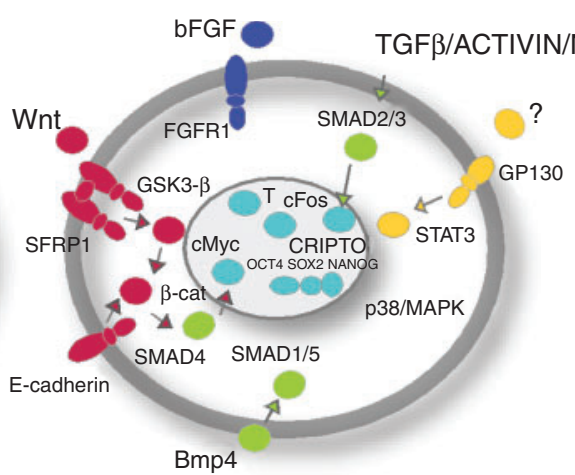

Porcine TE (D10)

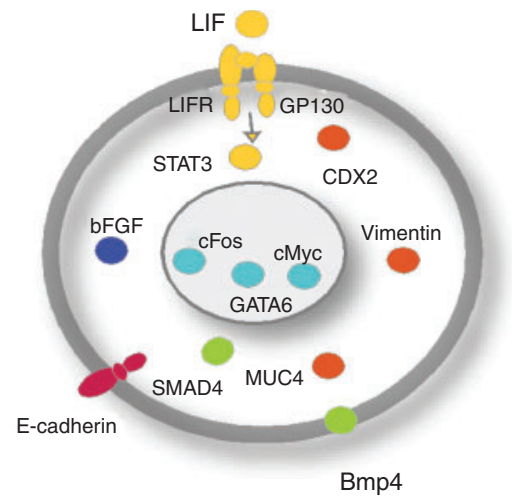

Fig. 1. Postulated cell signalling events in the porcine inner cell mass (ICM), epiblast (EPI) and trophectoderm (TE) compared with mouse embryonic stem cells (mESC) and human embryonic stem cells (hESC) indicates that the porcine blastocyst expresses few genes related to WNT and bone morphogenetic protein (BMP) signalling, whereas the pluripotent EPI likely has an active fibroblast growth factor (FGF), WNT, BMP and transforming growth factor (TGF)- $\beta$ /ACTIVIN/NODAL signalling pathway. Little is known about the expression of the porcine TE from the Day 6 blastocyst; however, basic (b) FGF is produced from the TE of the Embryonic day 10 embryo and the leukaemia inhibitory factor (LIF) signalling pathway may be active, given the observed expression of LIF receptor (LIFR), Glyocprotein 130 (GP130) and Signal transducer and activator of transcription 3 (STAT3).

small mitochondria with only few cristae, small Golgi complexes, sparse smooth and rough endoplasmic reticulum and rare observations of mitosis (Hall et al. 2010), which may indicate that, at this stage of embryo development, the pluripotent cells may enter a short period of dormancy or a rest state. This could explain, in part, why few genes are expressed. Transcriptional profiling of these cells could help reveal other genes important during this stage of development. 


\section{Potential cell signalling pathways in the porcine EPI and corresponding TE}

Investigations into various genes associated with pluripotency reveal that the EPI expresses many of these genes compared with expression in the earlier ICM. We have found that the $S M A D$ genes and genes associated with BMP cell signalling are expressed in the porcine EPI (V. J. Hall and P. Hyttel, unpubl. data). Expression of SMAD1, SMAD2, SMAD3 and SMAD5 can be detected in the isolated EPI from the later Day 10 embryo, which may indicate that these genes are transcribed. Furthermore, SMAD4 and BMP4 can be detected in pooled EPIs of the same developmental stage. In the case of WNT signalling, the SFRP 1, GSK $3 b$ and $\beta$-catenin genes can be detected in the porcine EPI, but that only the gene encoding $\beta$-catenin can be detected in the earlier porcine blastocyst. These observations indicate the presence of active WNT signalling only in the laterstage pluripotent EPI. In the case of JAK/STAT signalling, GP130 and STAT3 are expressed in the porcine EPI, indicating that JAK/STAT signalling is present but is not activated by LIF (V. J. Hall and P. Hyttel, unpubl. data). These observations, together with previously published reports (Kuijk et al. 2008; Hall et al. 2009, 2010; Wolf et al. 2011b, 2011c), reveal several different potentially active pathways in the EPI (Fig. 1). At this point, little is known about TGF- $\beta$ and BMP receptor expression and therefore receptors for these pathways are not shown in Fig. 1. In summary, the porcine EPI appears to exhibit a more 'active' state of pluripotency compared with the porcine ICM, in which more commonly associated cell signalling genes of pluripotency are expressed. It appears that FGF signalling is involved, given the expression of $F G F R 1$, however information regarding the expression of other FGF receptors is required. Given that bFGF is expressed and likely secreted from the porcine TE (Hall et al. 2009), this could be a significant proximal source for governing cell proliferation.

Very little is known about the genes expressed in the TE of porcine preimplantation embryos. However, we have found that the TE expresses BMP4 and SMAD4. In addition, the TE expresses LIFR, GP130 and STAT3, indicative of a likely active JAK/STAT signalling pathway activated by LIF (V. J. Hall and P. Hyttel, unpubl. data). Although the TE did not express FGFR1, it was found to express $c-M y c$ (V. J. Hall and P. Hyttel, unpubl. data). Whyte and Stewart (1989) have detected $c$-Fos expression in the TE at this stage, and CDX2 and GATA6 are expressed in the TE of Embryonic day 10 embryos (Gao et al. 2011a), which suggests that these genes associated with differentiation of the TE in the mouse, may likely be conserved (Koutsourakis et al. 1999; Strumpf et al. 2005). An overview of known genes and potentially active pathways in the TE of both Day 6 and Day 10 porcine embryo is shown in Fig. 1 based on our own unpublished findings and previously published reports (Hall et al. 2009).

\section{Conclusion}

In summary, this paper provides an overview of known gene expression in the developing porcine preimplantation embryo, specifically that of genes expressed in the pluripotent ICM and EPI and corresponding TE. Few genes associated with pluripotency in mouse and human have been found in the early porcine embryo containing the ICM and, despite uncovering potentially active pathways in the porcine EPI, little progress has been made in establishing a stable pESC, because neither bFGF nor LIF can support the long-term growth of $\mathrm{pESC}$ in vitro. Transcription profiling could help uncover novel transcription factors and cell signalling pathways that regulate pluripotency in the ICM and help determine more about the cell signalling pathways in the EPI. Furthermore, the addition of cell signalling inhibitors to cultured piPSC and embryonic cells could help reveal which cell signalling pathways are crucial in the regulation of cell renewal and proliferation. The composition of the culture media has been shown in many recent studies to impact significantly on the in vitro stem cell state. Pluripotent iPSC can form neural stem cells during a transient period after reprogramming when cultured in a neural medium (Kim et al. 2011) and hESC can form mESC-like cells simply by altering the culture conditions (Gu et al. 2012). Thus, determining the cell signalling cascades and the activators of these cascades in the porcine ICM and EPI will help improve culture conditions, which could lead to future establishment of bona fide pluripotent cells and stable iPSC.

\section{Acknowledgements}

The author's work described herein was supported financially by European Union (EU) projects (EU FP7 PartnErS, PluriSys and HEALTH-2007-B223485), the Danish National Advanced Technology Foundation, Pigs and Health Project, and the Danish Council for Independent Research, Technology and Production Science in Denmark.

\section{References}

Alberio, R., Croxall, N., and Allegrucci, C. (2010). Pig epiblast stem cells depend on activin/nodal signaling for pluripotency and self-renewal. Stem Cells Dev. 19, 1627-1636. doi:10.1089/SCD.2010.0012

Bazer, F. W., Spencer, T. E., Johnson, G. A., Burghardt, R. C., and Wu, G. (2009). Comparative aspects of implantation. Reproduction 138, 195-209. doi:10.1530/REP-09-0158

Bernemann, C., Greber, B., Ko, K., Sterneckert, J., Han, D. W., ArauzoBravo, M. J., and Scholer, H. R. (2011). Distinct developmental ground states of epiblast stem cell lines determine different pluripotency features. Stem Cells 29, 1496-1503. doi:10.1002/STEM.709

Bode, G., Clausing, P., Gervais, F., Loegsted, J., Luft, J., Nogues, V., and Sims, J. (2010). The utility of the minipig as an animal model in regulatory toxicology. J. Pharmacol. Toxicol. Methods 62, 196-220. doi:10.1016/J.VASCN.2010.05.009

Bourque, G., Leong, B., Vega, V. B., Chen, X., Lee, Y. L., Srinivasan, K. G., Chew, J. L., Ruan, Y., Wei, C. L., Ng, H. H., and Liu, E. T. (2008). Evolution of the mammalian transcription factor binding repertoire via transposable elements. Genome Res. 18, 1752-1762. doi:10.1101/GR. 080663.108

Brevini, T. A., Antonini, S., Cillo, F., Crestan, M., and Gandolfi, F. (2007a) Porcine embryonic stem cells: facts, challenges and hopes. Theriogenology 68(Suppl. 1), S206-S213. doi:10.1016/J.THERIOGENOLOGY. 2007.05.043

Brevini, T. A., Tosetti, V., Crestan, M., Antonini, S., and Gandolfi, F. (2007b). Derivation and characterization of pluripotent cell lines from pig embryos of different origins. Theriogenology 67, 54-63. doi:10.1016/J.THERIOGENOLOGY.2006.09.019

Brons, I. G., Smithers, L. E., Trotter, M. W., Rugg-Gunn, P., Sun, B., Chuva de Sousa Lopes, S. M., Howlett, S. K., Clarkson, A., Ahrlund-Richter, L., 
Pedersen, R. A., and Vallier, L. (2007). Derivation of pluripotent epiblast stem cells from mammalian embryos. Nature 448, 191-195. doi:10.1038/NATURE05950

Cauffman, G., Liebaers, I., Van Steirteghem, A., and Van de Velde, H. (2006). POU5F1 isoforms show different expression patterns in human embryonic stem cells and preimplantation embryos. Stem Cells 24, 2685-2691. doi:10.1634/STEMCELLS.2005-0611

Chambers, I., Silva, J., Colby, D., Nichols, J., Nijmeijer, B., Robertson, M., Vrana, J., Jones, K., Grotewold, L., and Smith, A. (2007). Nanog safeguards pluripotency and mediates germline development. Nature 450, 1230-1234. doi:10.1038/NATURE06403

Chen, X., Xu, H., Yuan, P., Fang, F., Huss, M., Vega, V. B., Wong, E., Orlov, Y. L., Zhang, W., Jiang, J., et al. (2008). Integration of external signaling pathways with the core transcriptional network in embryonic stem cells. Cell 133, 1106-1117. doi:10.1016/J.CELL.2008.04.043

Clark, K. J., Carlson, D. F., and Fahrenkrug, S. C. (2007). Pigs taking wing with transposons and recombinases. Genome Biol. 8(Suppl. 1), S13-S13.16. doi:10.1186/GB-2007-8-S1-S13

Cole, M. F., Johnstone, S. E., Newman, J. J., Kagey, M. H., and Young, R. A. (2008). Tcf3 is an integral component of the core regulatory circuitry of embryonic stem cells. Genes Dev. 22, 746-755. doi:10.1101/GAD. 1642408

Dang-Nguyen, T. Q., Somfai, T., Haraguchi, S., Kikuchi, K., Tajima, A., Kanai, Y., and Nagai, T. (2011). In vitro production of porcine embryos: current status, future perspectives and alternative applications. Anim. Sci. J. 82, 374-382.

Dejosez, M., Levine, S. S., Frampton, G. M., Whyte, W. A., Stratton, S. A., Barton, M. C., Gunaratne, P. H., Young, R. A., and Zwaka, T. P. (2010). Ronin/Hcf- 1 binds to a hyperconserved enhancer element and regulates genes involved in the growth of embryonic stem cells. Genes Dev. 24, 1479-1484. doi:10.1101/GAD.1935210

Ding, V. M., Ling, L., Natarajan, S., Yap, M. G., Cool, S. M., and Choo, A. B. (2010). FGF-2 modulates Wnt signaling in undifferentiated hESC and iPS cells through activated PI3-K/GSK3beta signaling. J. Cell. Physiol. 225, 417-428. doi:10.1002/JCP.22214

du Puy, L., Lopes, S. M., Haagsman, H. P., and Roelen, B. A. (2011). Analysis of co-expression of OCT4, NANOG and SOX2 in pluripotent cells of the porcine embryo, in vivo and in vitro. Theriogenology 75, 513-526. doi:10.1016/J.THERIOGENOLOGY. 2010.09.019

Eiselleova, L., Matulka, K., Kriz, V., Kunova, M., Schmidtova, Z., Neradil, J., Tichy, B., Dvorakova, D., Pospisilova, S., Hampl, A., and Dvorak, P. (2009). A complex role for FGF-2 in self-renewal, survival, and adhesion of human embryonic stem cells. Stem Cells 27, 1847-1857. doi:10.1002/ STEM. 128

Esteban, M. A., Xu, J., Yang, J., Peng, M., Qin, D., Li, W., Jiang, Z., Chen, J., Deng, K., Zhong, M., Cai, J., Lai, L., and Pei, D. (2009). Generation of induced pluripotent stem cell lines from Tibetan miniature pig. J. Biol. Chem. 284, 17 634-17 640. doi:10.1074/JBC.M109.008938

Esteban, M. A., Peng, M., Deli, Z., Cai, J., Yang, J., Xu, J., Lai, L., and Pei, D. (2010). Porcine induced pluripotent stem cells may bridge the gap between mouse and human iPS. IUBMB Life 62, 277-282.

Ezashi, T., Telugu, B. P., Alexenko, A. P., Sachdev, S., Sinha, S., and Roberts, R. M. (2009). Derivation of induced pluripotent stem cells from pig somatic cells. Proc. Natl Acad. Sci. USA 106, 10993-10998. doi:10.1073/PNAS.0905284106

Fahrenkrug, S. C., Blake, A., Carlson, D. F., Doran, T., Van Eenennaam, A., Faber, D., Galli, C., Gao, Q., Hackett, P. B., Li, N., et al. (2010). Precision genetics for complex objectives in animal agriculture. J. Anim. Sci. 88, 2530-2539. doi:10.2527/JAS.2010-2847

Gao, Y., Hyttel, P., and Hall, V. J. (2010). Regulation of H3K27me3 and H3K4me3 during early porcine embryonic development. Mol. Reprod. Dev. 77, 540-549. doi:10.1002/MRD. 21180
Gao, Y., Hyttel, P., and Hall, V. J. (2011a). Dynamic changes in epigenetic marks and gene expression during porcine epiblast specification. Cell. Reprogram. 13, 345-360. doi:10.1089/CELL.2010.0110

Gao, Y., Jammes, H., Rasmussen, M.A., Oestrup, O., Beaujean, N., Hall, V., and Hyttel, P. (2011b). Epigenetic regulation of gene expression in porcine epiblast, hypoblast, trophectoderm and epiblast-derived neural progenitor cells. Epigenetics 6, 1149-1161.

Garrels, W., Ivics, Z., and Kues, W. A. (2012). Precision genetic engineering in large mammals. Trends Biotechnol. 30, 386-393. doi:10.1016/ J.TIBTECH.2012.03.008

Gil, M. A., Cuello, C., Parrilla, I., Vazquez, J. M., Roca, J., and Martinez, E. A. (2010). Advances in swine in vitro embryo production technologies. Reprod. Domest. Anim. 45(Suppl. 2), 40-48. doi:10.1111/J.14390531.2010.01623.X

Greber, B., Wu, G., Bernemann, C., Joo, J. Y., Han, D. W., Ko, K., Tapia, N., Sabour, D., Sterneckert, J., Tesar, P., and Schöler, H. R. (2010). Conserved and divergent roles of FGF signaling in mouse epiblast stem cells and human embryonic stem cells. Cell Stem Cell 6, 215-226. doi:10.1016/J.STEM.2010.01.003

Gu, Q., Hao, J., Zhao, X.Y., Li, W., Liu, L., Wang, L., Liu, Z. H., and Zhou, Q. (2012). Rapid conversion of human ESCs into mouse ESC-like pluripotent state by optimizing culture conditions. Protein Cell 3, 71-79. doi:10.1007/S13238-012-2007-8

Hall, V. (2008). Porcine embryonic stem cells: a possible source for cell replacement therapy. Stem Cell Rev. 4, 275-282. doi:10.1007/S12015008-9040-2

Hall, V. J., Christensen, J., Gao, Y., Schmidt, M. H., and Hyttel, P. (2009). Porcine pluripotency cell signaling develops from the inner cell mass to the epiblast during early development. Dev. Dyn. 238, 2014-2024. doi:10.1002/DVDY.22027

Hall, V. J., Jacobsen, J. V., Rasmussen, M. A., and Hyttel, P. (2010). Ultrastructural and molecular distinctions between the porcine inner cell mass and epiblast reveal unique pluripotent cell states. Dev. Dyn. 239, 2911-2920. doi:10.1002/DVDY.22424

Hall, V. J., Kristensen, M., Rasmussen, M. A., Ujhelly, O., Dinnyes, A., and Hyttel, P. (2012). Temporal repression of endogenous pluripotency genes during reprogramming of porcine induced pluripotent stem cells. Cell. Reprogram. 14, 204-216.

Han, D. W., Tapia, N., Joo, J. Y., Greber, B., Arauzo-Bravo, M. J., Bernemann, C., Ko, K., Wu, G., Stehling, M., Do, J. T., and Schöler, H. R. (2010). Epiblast stem cell subpopulations represent mouse embryos of distinct pregastrulation stages. Cell 143, 617-627. doi:10.1016/ J.CELL.2010.10.015

Hao, J., Li, T. G., Qi, X., Zhao, D. F., and Zhao, G. Q. (2006). WNT/betacatenin pathway up-regulates Stat3 and converges on LIF to prevent differentiation of mouse embryonic stem cells. Dev. Biol. 290, 81-91. doi:10.1016/J.YDBIO.2005.11.011

Harvey, A. J., Armant, D. R., Bavister, B. D., Nichols, S. M., and Brenner, C. A. (2009). Inner cell mass localization of NANOG precedes OCT3/4 in rhesus monkey blastocysts. Stem Cells Dev. 18, 1451-1458. doi: $10.1089 / \mathrm{SCD} .2009 .0122$

Hayashi, K., Lopes, S. M., Tang, F., and Surani, M. A. (2008). Dynamic equilibrium and heterogeneity of mouse pluripotent stem cells with distinct functional and epigenetic states. Cell Stem Cell 3, 391-401. doi:10.1016/J.STEM.2008.07.027

Henderson, J. K., Draper, J. S., Baillie, H. S., Fishel, S., Thomson, J. A., Moore, H., and Andrews, P. W. (2002). Preimplantation human embryos and embryonic stem cells show comparable expression of stage-specific embryonic antigens. Stem Cells 20, 329-337. doi:10.1634/STEM CELLS.20-4-329

Hirai, H., Karian, P., and Kikyo, N. (2011). Regulation of embryonic stem cell self-renewal and pluripotency by leukaemia inhibitory factor. Biochem. J. 438, 11-23. doi:10.1042/BJ20102152 
Jacobs, A. (2006). Use of nontraditional animals for evaluation of pharmaceutical products. Expert Opin. Drug Metab. Toxicol. 2, 345-349. doi:10.1517/17425255.2.3.345

Kang, H. B., Kim, J. S., Kwon, H. J., Nam, K. H., Youn, H. S., Sok, D. E., and Lee, Y. (2005). Basic fibroblast growth factor activates ERK and induces c-fos in human embryonic stem cell line MizhES1. Stem Cells Dev. 14, 395-401. doi:10.1089/SCD.2005.14.395

Kim, J., Chu, J., Shen, X., Wang, J., and Orkin, S. H. (2008). An extended transcriptional network for pluripotency of embryonic stem cells. Cell 132, 1049-1061. doi:10.1016/J.CELL.2008.02.039

Kim, J., Efe, J. A., Zhu, S., Talantova, M., Yuan, X., Wang, S., Lipton, S. A., Zhang, K., and Ding, S. (2011). Direct reprogramming of mouse fibroblasts to neural progenitors. Proc. Natl Acad. Sci. USA 108 , 7838-7843. doi:10.1073/PNAS.1103113108

Klymiuk, N., Mundhenk, L., Kraehe, K., Wuensch, A., Plog, S., Emrich, D., Langenmayer, M. C., Stehr, M., Holzinger, A., Kröner, C., et al. (2012). Sequential targeting of CFTR by BAC vectors generates a novel pig model of cystic fibrosis. J. Mol. Med. 90, 597-608. doi:10.1007/S00109011-0839-Y

Koutsourakis, M., Langeveld, A., Patient, R., Beddington, R., and Grosveld, F. (1999). The transcription factor GATA6 is essential for early extraembryonic development. Development 126, 723-732.

Kragh, P. M., Nielsen, A. L., Li, J., Du, Y., Lin, L., Schmidt, M., Bogh, I. B., Holm, I. E., Jakobsen, J. E., Johansen, M. G., Purup, S., Bolund, L., Vajta, G., and Jørgensen, A. L. (2009). Hemizygous minipigs produced by random gene insertion and handmade cloning express the Alzheimer's disease-causing dominant mutation APPsw. Transgenic Res. 18, 545-558. doi:10.1007/S11248-009-9245-4

Kuijk, E. W., Du Puy, L., Van Tol, H. T., Oei, C. H., Haagsman, H. P., Colenbrander, B., and Roelen, B. A. (2008). Differences in early lineage segregation between mammals. Dev. Dyn. 237, 918-927. doi:10.1002/ DVDY. 21480

Kunarso, G., Chia, N. Y., Jeyakani, J., Hwang, C., Lu, X., Chan, Y. S., Ng, H. H., and Bourque, G. (2010). Transposable elements have rewired the core regulatory network of human embryonic stem cells. Nat. Genet. $\mathbf{4 2}$ 631-634. doi:10.1038/NG.600

Lermen, D., Gorjup, E., Dyce, P. W., von Briesen, H., and Muller, P. (2010). Neuro-muscular differentiation of adult porcine skin derived stem cell-like cells. PLoS One 5, e8968. doi:10.1371/JOURNAL.PONE.0008968

Liard, O., Segura, S., Pascual, A., Gaudreau, P., Fusai, T., and Moyse, E. (2009). In vitro isolation of neural precursor cells from the adult pig subventricular zone. J. Neurosci. Methods 182, 172-179. doi:10.1016/ J.JNEUMETH.2009.06.008

Liu, Y., Ostrup, O., Li, J., Vajta, G., Lin, L., Kragh, P. M., Purup, S., Hyttel, P., and Callesen, H. (2012). Increased blastocyst formation of cloned porcine embryos produced with donor cells pre-treated with Xenopus egg extract and/or digitonin. Zygote 20, 61-66. doi:10.1017/ S096719941000064X

Luo, Y., Lin, L., Bolund, L., Jensen, T. G., and Sorensen, C. B. (2012). Genetically modified pigs for biomedical research. J. Inherit. Metab. Dis. 35, 695-713. doi:10.1007/S10545-012-9475-0

Macfarlan, T. S., Gifford, W. D., Driscoll, S., Lettieri, K., Rowe, H. M., Bonanomi, D., Firth, A., Singer, O., Trono, D., and Pfaff, S. L. (2012). Embryonic stem cell potency fluctuates with endogenous retrovirus activity. Nature 487, 57-63.

Maherali, N., and Hochedlinger, K. (2008). Guidelines and techniques for the generation of induced pluripotent stem cells. Cell Stem Cell $\mathbf{3}$, 595-605. doi:10.1016/J.STEM.2008.11.008

Masui, S., Nakatake, Y., Toyooka, Y., Shimosato, D., Yagi, R., Takahashi, K., Okochi, H., Okuda, A., Matoba, R., Sharov, A. A., Ko, M .S. H., and Niwa, H. (2007). Pluripotency governed by Sox 2 via regulation of Oct3/ 4 expression in mouse embryonic stem cells. Nat. Cell Biol. 9, 625-635. doi:10.1038/NCB1589
McAnulty, P. A., Dayan, A. D., Ganderup, N.-C., and Hastings, K. L. (2011) 'The Minipig in Biomedical Research.' (CRC Press: London.)

Miernik, K., and Karasinski, J. (2012). Porcine uterus contains a population of mesenchymal stem cells. Reproduction 143, 203-209. doi:10.1530/ REP-11-0202

Monaco, E., Bionaz, M., Hollister, S. J., and Wheeler, M. B. (2011) Strategies for regeneration of the bone using porcine adult adiposederived mesenchymal stem cells. Theriogenology 75, 1381-1399. doi:10.1016/J.THERIOGENOLOGY.2010.11.020

Montserrat, N., de Onate, L., Garreta, E., Gonzalez, F., Adamo, A., Eguizabal, C., Hafner, S., Vassena, R., and Belmonte, J. C. (2011). Generation of feeder free pig induced pluripotent stem cells without Pou5f1. Cell Transplant. [Epub ahead of print].

Moore, K., and Piedrahita, J. A. (1997). The effects of human leukemia inhibitory factor (hLIF) and culture medium on in vitro differentiation of cultured porcine inner cell mass (pICM). In Vitro Cell. Dev. Biol. Anim. 33, 62-71. doi:10.1007/S11626-997-0023-4

Muñoz, M., Trigal, B., Molina, I., Díez, C., Caamaño, J. N., and Gómez, E. (2009). Constraints to progress in embryonic stem cells from domestic species. Stem Cell Rev. 5, 6-9. doi:10.1007/S12015-009-9052-6

Ng, H. H., and Surani, M. A. (2011). The transcriptional and signalling networks of pluripotency. Nat. Cell Biol. 13, 490-496. doi:10.1038/ NCB0511-490

Nguyen, N. T., Lo, N. W., Chuang, S. P., Jian, Y. L., and Ju, J. C. (2011) Sonic hedgehog supplementation of oocyte and embryo culture media enhances development of IVF porcine embryos. Reproduction 142, 87-97. doi:10.1530/REP-11-0049

Niwa, H., Miyazaki, J., and Smith, A. G. (2000). Quantitative expression of Oct-3/4 defines differentiation, dedifferentiation or self-renewal of ES cells. Nat. Genet. 24, 372-376. doi:10.1038/74199

O’Leary, T., Heindryckx, B., Lierman, S., van Bruggen, D., Goeman, J. J., Vandewoestyne, M., Deforce, D., de Sousa Lopes, S. M., and De Sutter, P. (2012). Tracking the progression of the human inner cell mass during embryonic stem cell derivation. Nat. Biotechnol. 30, 278-282. doi:10.1038/NBT.2135

Oestrup, O., Hall, V., Petkov, S. G., Wolf, X. A., Hyldig, S., and Hyttel, P. (2009). From zygote to implantation: morphological and molecular dynamics during embryo development in the pig. Reprod. Domest. Amin. 44(Suppl. 3), 39-49. doi:10.1111/J.1439-0531.2009. 01482.X

Petkov, S. G., Marks, H., Klein, T., Garcia, R. S., Gao, Y., Stunnenberg, H., and Hyttel, P. (2011). In vitro culture and characterization of putative porcine embryonic germ cells derived from domestic breeds and Yucatan mini pig embryos at Days 20-24 of gestation. Stem Cell Res. 6, 226-237. doi:10.1016/J.SCR.2011.01.003

Price, E. M., Prather, R. S., and Foley, C. M. (2006). Multipotent adult progenitor cell lines originating from the peripheral blood of green fluorescent protein transgenic swine. Stem Cells Dev. 15, 507-522. doi:10.1089/SCD.2006.15.507

Puy, L., Chuva de Sousa Lopes, S. M., Haagsman, H. P., and Roelen, B. A. (2010). Differentiation of porcine inner cell mass cells into proliferating neural cells. Stem Cells Dev. 19, 61-70. doi:10.1089/ SCD.2009.0075

Rasmussen, M. A., Hall, V. J., Carter, T. F., and Hyttel, P. (2011). Directed differentiation of porcine epiblast-derived neural progenitor cells into neurons and glia. Stem Cell Res. 7, 124-136. doi:10.1016/J.SCR.2011. 04.004

Renner, S., Fehlings, C., Herbach, N., Hofmann, A., von Waldthausen, D. C., Kessler, B., Ulrichs, K., Chodnevskaja, I., Moskalenko, V., Amselgruber, W., Göke, B., Pfeifer, A., Wanke, R., and Wolf, E. (2010). Glucose intolerance and reduced proliferation of pancreatic beta-cells in transgenic pigs with impaired glucose-dependent insulinotropic polypeptide function. Diabetes 59, 1228-1238. doi:10.2337/DB09-0519 
Rho, G. J., Kumar, B. M., and Balasubramanian, S. S. (2009). Porcine mesenchymal stem cells: current technological status and future perspective. Front. Biosci. 14, 3942-3961. doi:10.2741/3503

Roberts, R. M., Telugu, B. P., and Ezashi, T. (2009). Induced pluripotent stem cells from swine (Sus scrofa): why they may prove to be important. Cell Cycle 8, 3078-3081. doi:10.4161/CC.8.19.9589

Rogers, C. S., Stoltz, D. A., Meyerholz, D. K., Ostedgaard, L. S., Rokhlina, T., Taft, P. J., Rogan, M. P., Pezzulo, A. A., Karp, P. H., Itani, O. A., et al. (2008). Disruption of the CFTR gene produces a model of cystic fibrosis in newborn pigs. Science 321, 1837-1841. doi:10.1126/SCIENCE. 1163600

Rugg-Gunn, P. J., Cox, B. J., Lanner, F., Sharma, P., Ignatchenko, V., McDonald, A. C., Garner, J., Gramolini, A. O., Rossant, J., and Kislinger, T. (2012). Cell-surface proteomics identifies lineage-specific markers of embryo-derived stem cells. Dev. Cell 22, 887-901. doi:10.1016/J.DEVCEL.2012.01.005

Saxe, J. P., Tomilin, A., Scholer, H. R., Plath, K., and Huang, J. (2009). Posttranslational regulation of Oct4 transcriptional activity. PLoS One 4, e4467. doi:10.1371/JOURNAL.PONE.0004467

Spitzer, N., Sammons, G. S., Butts, H. M., Grover, L. M., and Price, E. M. (2011). Multipotent progenitor cells derived from adult peripheral blood of swine have high neurogenic potential in vitro. J. Cell. Physiol. 226, 3156-3168. doi:10.1002/JCP. 22670

Staunstrup, N. H., Madsen, J., Primo, M. N., Li, J., Liu, Y., Kragh, P. M., Li, R., Schmidt, M., Purup, S., Dagnaes-Hansen, F., Svensson, L., Petersen, T. K., Callesen, H., Bolund, L., and Mikkelsen, J. G. (2012). Development of transgenic cloned pig models of skin inflammation by DNA transposon-directed ectopic expression of human beta 1 and alpha2 integrin. PLoS One 7, e36658. doi:10.1371/JOURNAL.PONE.0036658

Strumpf, D., Mao, C. A., Yamanaka, Y., Ralston, A., Chawengsaksophak, K., Beck, F., and Rossant, J. (2005). Cdx2 is required for correct cell fate specification and differentiation of trophectoderm in the mouse blastocyst. Development 132, 2093-2102. doi:10.1242/DEV.01801

Suzuki, S., Iwamoto, M., Saito, Y., Fuchimoto, D., Sembon, S., Suzuki, M., Mikawa, S., Hashimoto, M., Aoki, Y., Najima, Y., et al. (2012). I12rg gene-targeted severe combined immunodeficiency pigs. Cell Stem Cell 10, 753-758. doi:10.1016/J.STEM.2012.04.021

Tareq, K. M., Akter, Q. S., Khandoker, M. A., and Tsujii, H. (2012). Selenium and vitamin $\mathrm{E}$ improve the in vitro maturation, fertilization and culture to blastocyst of porcine oocytes. J. Reprod. Dev. [Epub ahead of print]. doi:10.1262/JRD.2012-064

Telugu, B. P., Ezashi, T., Sinha, S., Alexenko, A. P., Spate, L., Prather, R. S., and Roberts, R. M. (2011). Leukemia inhibitory factor (LIF)-dependent, pluripotent stem cells established from inner cell mass of porcine embryos. J. Biol. Chem. 286, 28 948-28 953. doi:10.1074/JBC.M111. 229468

ten Berge, D., Kurek, D., Blauwkamp, T., Koole, W., Maas, A., Eroglu, E., Siu, R. K., and Nusse, R. (2011). Embryonic stem cells require Wnt proteins to prevent differentiation to epiblast stem cells. Nat. Cell Biol. 13, 1070-1075. doi:10.1038/NCB2314

Uebing-Czipura, A. U., Dawson, H. D., and Scherba, G. (2008). Immortalization and characterization of lineage-restricted neuronal progenitor cells derived from the porcine olfactory bulb. J. Neurosci. Methods 170, 262-276. doi:10.1016/J.JNEUMETH.2008.01.028

Vejlsted, M., Offenberg, H., Thorup, F., and Maddox-Hyttel, P. (2006). Confinement and clearance of OCT4 in the porcine embryo at stereomicroscopically defined stages around gastrulation. Mol. Reprod. Dev. 73, 709-718. doi:10.1002/MRD.20461

Wang, J., Levasseur, D. N., and Orkin, S. H. (2008). Requirement of Nanog dimerization for stem cell self-renewal and pluripotency. Proc. Natl Acad. Sci. USA 105, 6326-6331. doi:10.1073/PNAS.0802288105
Wang, Z., Oron, E., Nelson, B., Razis, S., and Ivanova, N. (2012). Distinct lineage specification roles for NANOG, OCT4, and SOX2 in human embryonic stem cells. Cell Stem Cell 10, 440-454. doi:10.1016/J.STEM. 2012.02.016

West, F. D., Terlouw, S. L., Kwon, D. J., Mumaw, J. L., Dhara, S. K., Hasneen, K., Dobrinsky, J. R., and Stice, S. L. (2010). Porcine induced pluripotent stem cells produce chimeric offspring. Stem Cells Dev. 19 , 1211-1220. doi:10.1089/SCD.2009.0458

West, F. D., Uhl, E. W., Liu, Y., Stowe, H., Lu, Y., Yu, P., GallegosCardenas, A., Pratt, S. L., and Stice, S. L. (2011). Brief report: chimeric pigs produced from induced pluripotent stem cells demonstrate germline transmission and no evidence of tumor formation in young pigs. Stem Cells 29, 1640-1643. doi:10.1002/STEM.713

Whyte, A., and Stewart, H. J. (1989). Expression of the proto-oncogene fos (c-fos) by preimplantation blastocysts of the pig. Development 105, 651-656.

Wianny, F., Perreau, C., and Hochereau de Reviers, M. T. (1997). Proliferation and differentiation of porcine inner cell mass and epiblast in vitro. Biol. Reprod. 57, 756-764. doi:10.1095/BIOLREPROD57.4.756

Wolf, X. A., Rasmussen, M. A., Schauser, K., Jensen, A. T., Schmidt, M., and Hyttel, P. (2011a). OCT4 expression in outgrowth colonies derived from porcine inner cell masses and epiblasts. Reprod. Domest. Anim. 46, 385-392. doi:10.1111/J.1439-0531.2010.01675.X

Wolf, X. A., Serup, P., and Hyttel, P. (2011b). Three-dimensional immunohistochemical characterization of lineage commitment by localization of $\mathrm{T}$ and FOXA2 in porcine peri-implantation embryos. Dev. Dyn. 240 , 890-897. doi:10.1002/DVDY.22602

Wolf, X. A., Serup, P., and Hyttel, P. (2011c). Three-dimensional localisation of NANOG, OCT4, and E-CADHERIN in porcine pre- and periimplantation embryos. Dev. Dyn. 240, 204-210. doi:10.1002/DVDY. 22491

Wu, Z., Chen, J., Ren, J., Bao, L., Liao, J., Cui, C., Rao, L., Li, H., Gu, Y., Dai, H., Zhu, H., Teng, X., Cheng, L., and Xiao, L. (2009). Generation of pig induced pluripotent stem cells with a drug-inducible system. J. Mol. Cell Biol. 1, 46-54. doi:10.1093/JMCB/MJP003

Yin, F., Guo, L., Lu, R. F., and Zhu, Q. S. (2011). Spontaneous differentiation of porcine neural progenitors in vitro. Cytotechnology 63, 363-370. doi: 10.1007/S10616-011-9353-X

Yoshioka, K. (2011). Development and application of a chemically defined medium for the in vitro production of porcine embryos. J. Reprod. Dev. 57, 9-16. doi:10.1262/JRD.10-196E

Zhao, J., Whyte, J., and Prather, R. S. (2010). Effect of epigenetic regulation during swine embryogenesis and on cloning by nuclear transfer. Cell Tissue Res. 341, 13-21. doi:10.1007/S00441-010-1000-X

Zhao, M., Isom, S. C., Lin, H., Hao, Y., Zhang, Y., Zhao, J., Whyte, J. J., Dobbs, K. B., and Prather, R. S. (2009). Tracing the stemness of porcine skin-derived progenitors (pSKP) back to specific marker gene expression. Cloning Stem Cells 11, 111-122. doi:10.1089/CLO.2008.0071

Zhao, M. T., Yang, X., Lee, K., Mao, J., Teson, J. M., Whitworth, K. M., Samuel, M. S., Spate, L. D., Murphy, C. N., and Prather, R. S. (2012). The in vivo developmental potential of porcine skin-derived progenitors and neural stem cells. Stem Cells Dev. [Epub ahead of print]. doi:10. 1089/SCD.2012.0067

Zhou, H., Li, W., Zhu, S., Joo, J. Y., Do, J. T., Xiong, W., Kim, J. B., Zhang, K., Scholer, H. R., and Ding, S. (2010). Conversion of mouse epiblast stem cells to an earlier pluripotency state by small molecules. J. Biol. Chem. 285, 29 676-29 680. doi:10.1074/JBC.C110.150599 